ADDIN, Volume 13, Number 1, February 2019

\title{
Syntax Errors in the Qur'an
}

\section{Fakhrur Razi Mohd Rafi}

Universitas Pendidikan Indonesia (UPI) Bandung, Indonesia ajiatek94@gmail.com

\section{Yayan Nurbayan}

Universitas Pendidikan Indonesia (UPI) Bandung, Indonesia yayannurbayan19@gmail.com

\section{Zaka Al Farisi}

Universitas Pendidikan Indonesia (UPI) Bandung, Indonesia zakafarisi75@gmail.com

\section{Abstract}

This research is motivated by the thought of an orientalist'Abdallah 'Abd al-Fadi-which states that the Qur'an has no perfection. He poured his thoughts into a book Is the Qur'an Infallible? In his book, he states that the Qur'an contains 22 Arabic syntax errors. His thoughts effected in many Muslims doubtful towards the authenticity of the Qur'an. In addition, non-Muslims also increasingly undermine the authenticity of it. Considering that this issue is a matter that must be addressed, the researcher will research further in this case. The purpose of this study is to refute the thoughts of 'Abdallah 'Abd al-Fadi and to maintain the purity, image, and authenticity of the Qur'an. The research method used in this research is descriptive analysis with the qualitative approach. The finding of this research indicates that 'Abdallah 'Abd al-Fadi's thoughts on Qur'anic verses are wrong and this is due to his lack of 
understanding of Arabic theories especially the theories of Arabic syntax.

Keywords: Oriental Studies, Syntax Errors, Qur'an.

\section{Abstrak}

KESALAHAN SINTAKSIS DALAM AL-QUR'AN. Penelitian ini dilatarbelakangi oleh pemikiran seorang orientalis-'Abdallah 'Abd al-Fadi-yang menyatakan bahwa Al-Qur'an tidak memiliki kesempurnaan. Pemikirannya tersebut ia tuangkan ke dalam suatu buku yang diberi judul Is the Qur'an Infallible? (Apakah AlQur'an Itu Sempurna?). Dalam bukunya ia menyatakan bahwa Al-Qur'an memiliki 22 kesalahan sintaksis Arab. Pemikirannya tersebut mengakibatkan banyak muslim merasa ragu terhadap keotentikan Al-Qur'an. Selain itu, non-muslim juga semakin merendahan kesempurnaan kitab suci Al-Qur'an. Mengingat bahwa permasalahan ini merupakan suatu hal yang harus segera diatasi, maka peneliti meneliti lebih lanjut mengenai hal ini. Tujuan dilakukannya penelitian ini adalah untuk membantah pemikiran 'Abdallah 'Abd al-Fadi serta untuk menjaga kemurnian, citra, dan keotentikan Al-Qur'an. Metode penelitian yang digunakan dalam penelitian ini adalah metode analisis deskriptif dengan pendekatan kualitatif. Hasil dari penelitian ini menunjukkan bahwa pemikiran 'Abdallah 'Abd al-Fadi terhadap ayat-ayat Al-Qur'an adalah salah dan hal ini disebabkan oleh kurang fahamnya beliau terhadap teori-teori bahasa Arab terutama teori-teori ilmu sintaksis Arab.

Kata Kunci: Kajian Orientalis, Kesalahan Sintaksis, Al-Qur'an.

\section{A. Introduction}

The Arabic language is a unique language than any other languages. When compared with other languages, the uniqueness of Arabic language lies on its syntax. As it is known that the Arabic language is highly inflected language that assigns the role or function of a word according to its case ending, not according to its position in a sentence. For example, the word madrasab can be read with a 
rafa' sign, nashb, and jar according to the role. While in the English language, the uniqueness of syntax cannot be found.

Arabic syntax is very important in the Arabic language because language is a system consisting of components of phonology, morphology, syntax, and semantics. ${ }^{1}$ Therefore, it is required for everyone to master the syntax of a language to learn the language itself since the syntax is one of the most important components for learning a language. ${ }^{2}$ Therefore, mastering Arabic syntax is very important in learning the Arabic language. Indeed, Arabic syntax cannot be separated from other Arabic sciences. Arab syntax is also an important science in keeping the Arabic grammar theory from damaged and mixed with the dialect of 'Amiyyah. ${ }^{3}$

The famous Arabic syntax experts have focused their works on meanings and irab of the Qur'an. They also agree on the prescribed way of reading the Qur'an. So is their dependencies on Qur'an in establishing Arab syntax theories. Indeed, every word in the Qur'an contains the foundations of Arab syntax theory. ${ }^{4}$ Therefore, every theory that contained in Arabic syntax books comes from the Qur'an. The Qur'an is a reference book for Arab syntax experts. They also set the Qur'an as a guide that their theory is the correct theory.

However, there are still many people who deny the truth of the Qur'an and one of them is the orientalists. There are some orientalists explore and study the religion of Islam to defend Islam. William Montogomery is one orientalist who is claimed to be an objective and most sympathetic orientalist towards Islam. ${ }^{5}$

1 Jamat Jamil, "Fi'il Mu'tal dalam Buku Akblak lil Banin Juz 1 Karya Umar bin Ahmad Baraja': Analisis Morfofonemis", Journal of Arabic Learning and Teaching 3, no. 3 (2014): 15.

2 Ulil Albab, "Performansi dan Gramatika Bahasa Arab Sebagai Bahasa Kedua", Arabiyat: Jurnal Pendidikan Bahasa Arab dan Kebahasaaraban 2, no. 1 (2015): 75.

3 Toni Pransiska, "Konsep I'rab dalam Ilmu Nahwu", Jurnal al-Mabara 1, no. 1 (2015): 79 .

4 Muhammad al-Mukhtatar Walad Abbah, Tarikh an-Nabwiy al-Arabiy (Libanon: Dar al-Kutub al-'Tlmiyyah, 2008), 575.

5 Muhammad Roihan Daulay, "Studi Pendekatan Al-Qur'an”, Jurnal Thariqah Ilmiah 1, no. 1 (2014): 42. 
However, there are some orientalists who just wants to question and undermine people's belief in the perfection and authenticity of the Qur'an. One aspect that has been questioned by the orientalists against the perfection of the Qur'an is the aspect of its syntax which is judged to be contrary to the syntactic theories of Arabic. And it is reflected in a book entitled Is The Qur'an Infallible by 'Abdallah 'Abd al-Fadi.

Since centuries ago, linguists have admitted that the Qur'an is the Hakim of other Arabic sciences. The Qur'an is also the highest Arabic book of all aspects. ${ }^{6}$ Among the beauty of the Qur'an lies in the syntactic beauty. ${ }^{7}$

Therefore, if there is a contradiction between the syntactic theory and the Qur'an, empirically the errors are not derived from the syntactic theory and the Qur'an but derived from the orientalists that caused by their lack of understanding of the theories of Arabic especially the syntactic theories of the Arabic language.

\section{B. Discussion}

\section{1. 'Abdallah 'Abd al-Fadi's View to the Syntax Errors in the Qur'an}

Since centuries ago, the glory of Muslims has spread all over the world. Many mathematicians, astronomers, biologists, and others come from among the Muslims. So from that point, westerners have become interested in exploring and studying Arabic language and the religion of Islam since the 10th century. ${ }^{8}$ From the studies that have conducted by the westerners, many of them have compiled their studies into a book of approximately 60.000 books about the near orient. ${ }^{9}$

6 Muhammad Muhammad Daud, Kamal al-Lughah al-'Arabiyyah baina Haqa'iq alI'jaz wa Awham al-Khushum (al-Qahirah: Maktabah al-Adab, 2007), 21.

7 Muhammad Mahmud Qadli, I'rab Al-Qur'an Al-Karim (al-Qahirah: Dar ashShahwah, 2010), ii.

8 Muhammad Aqil Luthfan, "Orientalisme: antara Lawan dan Kawan", Jurnal Wahana Akademika 15, no. 1 (2013): 136.

9 Edward Wadie Said, Orientalism (London: Penguin Books, 2003), 204. 
However, need to know that among the orientalists who explore the Arabic language is not only for positive purposes such as the orientalist who devote himself solely to scientific knowledge. But there are some of the orientalists too who with negative purposes. ${ }^{10}$

Today, studies of orientalists become relevant for reappointment as adopting the ideas and views of orientalists is a trend among Muslim intellectuals. Talking about the orientalist issues that exploring and studying the religion of Islam, the main purpose of the studies by the orientalists is the study of Qur'an. ${ }^{11}$ They have always doubted and spread their doubts about the perfection and authenticity of Qur'an's contents so as to create doubts among Muslims against the holy book of Qur'an. ${ }^{12}$

Among the orientalists who with negative purposes was 'Abdallah 'Abd al-Fadi. In his writing, ${ }^{13}$ he states that the Qur'an has two Arabic syntactic errors that are not proper in the holy book of the Qur'an that is the Qur'an has no concordance between 'adad and ma'dud. The two errors are contained in Q.S. al-A'raf [7]: 160 and Q.S. at-Tahrim [66]: 4.

And in Q.S. al-A'raf [7]: 160 Allah says, "And We divided them into twelve tribes, each of which is large."

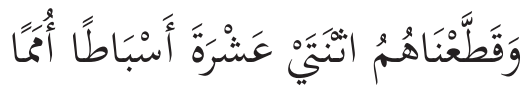

The Arabic rendering of this verse "Wa qattha'nahum ithnatay 'asyrata asbathan umaman". There are two grammatical errors in this verse. The first is the feminine number ithnatay 'asyrata, and the second is the plural noun asbathan. The word asbathan is masculine and requires a masculine number, also, a noun used in conjunction with a number 11 and 12 should be in a singular form. According to the theory of Arabic syntax for number 11 and 12 should be

10 Agustiar, "Orientalis dan Perannya dalam Mempelajari Bahasa Arab", Jurnal Usbuluddin 17, no. 2 (2011): 157.

11 Kurdi Fadal, "Pandangan Orientalis terhadap Al-Qur'an: "Teori Pengaruh" AlQur'an Theodor Nöldeke”, Jurnal Religia 14, no. 2 (2011): 190.

12 Fadal, 41

13 'Abdallah 'Abd al-Fadi, Is the Qur'an Infallible? (Austria: Light of Life, 2001), 173. 
concordance between 'adad and ma'dud in term of the gender and the ma'dud should be in a singular form. Therefore the Qur'an should have said ithnay 'ashara sibthan. ${ }^{14}$

Similarly, in Q.S. at-Tahrim [66]: 4 Allah says, "If you both repent to Allah, then surely your heart has been inclined (to receive kindness).”

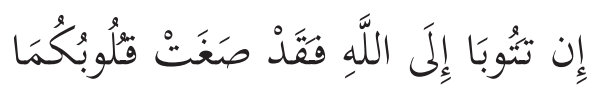

The Arabic rendering of this verse "In tatuba ila Allab fa qad shaghat qulubukuma". Al-Baidawi says that Hafsha and 'Aisyah were being addressed with this verse. But despite this, the Arabic word qulubukuma is in the plural form and it related to the pronoun kuma. There is an error in this verse because how can two people have more than two hearts. Therefore the Qur'an should have said qalbakuma. ${ }^{15}$

Thus the views of the orientalists who have been described above are empirical evidence that the Qur'an is a holy scripture that is still in doubt about its authenticity. From this empirical evidence, Zakaria Batrousin is one of the orientalists who concludes that the Qur'an is not Allah's creation. But the Qur'an is the creation of the prophet Muhammad because it is impossible for Allah to make a mistake. $^{16}$

\section{The Islamic Scholars' View to the Syntax Errors by} 'Abdallah 'Abd al-Fadi

Many of the orientalists reject and not accept the facts of the Qur'an that it is the most authentic and perfect Holy Scripture. The authenticity, excellence, and perfect of the Qur'an have been agreed upon by the Muslims and so are some the non-Muslims from the past to the present day from Morocco to Merauke. ${ }^{17}$

14 Al-Fadi, 175.

15 Al-Fadi, 185.

16 Amnah Tidjani, "Klarifikasi al-Darwish atas Pandangan Orientalis Tentang Kontradiksi Ayat Al-Qur'an dengan Kaidah Nahw", Mutawatir:Jurnal Keilmuan Tafsir Hadits 4, no. 1 (2014): 139.

17 Syamsuddin Arif, "Al-Qur'an, Orientalisme, dan Luxenberg", Afkar: Jurnal Akidah dan Pemikiran Islam 6, no. 1 (2005): 56. 
Therefore, many of the orientalists always try to spread their misguided thinking and idea to the whole world by saying that the Qur'an is not perfect. ${ }^{18}$ However, their efforts are all unsuccessful because the Qur'an is the first and primary source of law in the Islamic religion. ${ }^{19}$ So, it is really possible for a legal source which is the Qur'an to contain such an error.

Then the following is the result of research and discussion on the Arabic syntax errors in the Qur'an by 'Abdallah 'Abd alFadi. Two syntactic Arabic errors have been found that relate to the theory of 'adad and ma'dud in the Qur'an written in his book Is the Qur'an Infallible? Al-Fadi assumes that the verses contained in the Qur'an are not based on syntactic theories.

There are several theories relating to 'adad and ma'dud. Firstly, if the 'adad is between 3 and 10, the ma'dud must be in the plural form, the gender of the ma'dud must be the opposite of the gender of 'adad, and the ma'dud must be read with majrur. As for the 'adad between 11 and 99, the ma'dud must be in a singular form and the ma'dud must be read with manshub. And for 'adad 100, 1000, and so on, the ma'dud also must be in a singular form but the ma'dud must be read with majrur. ${ }^{20}$

So in Q.S. al-A'raf [7]: 160 Allah says, "And We divided them into twelve tribes, each of which is large."

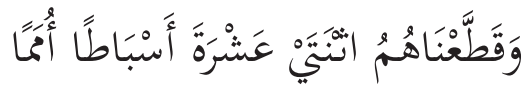

The Arabic rendering of this verse "Wa qattha'nabum ithnatay 'asyrata asbathan umaman". There are two grammatical errors in this verse. The first is the feminine number ithnatay 'asyrata, and the second is the plural noun asbathan. The word asbathan is masculine

18 Abdul Kholik, "Sunnah dalam Perspektif Orientalis", Jurnal El-Islam 2, no. 2 (2015): 216.

19 Khaeruddin Yusuf, “Orientalis dan Duplikasi Bahasa Al-Qur'an: Telaah dan Sanggahan atas Karya Christoph Luxenberg”, Hunafa: Jurnal Studia Islamika 9, no. 1 (2012): 150 . 2009), 558.

20 Muthafa al-Ghulayainiy, Jami' ad-Durus al-'Arabiyyah (al-Qahirah: Dar as-Salam, 
and requires a masculine number, also, a noun used in conjunction with a number 11 and 12 should be in a singular form. According to the theory of Arabic syntax for number 11 and 12 should be concordance between 'adad and ma'dud in term of the gender and the ma'dud should be in a singular form. Therefore the Qur'an should have said ithnay 'ashara sibthan. ${ }^{21}$

In fact what the orientalists believe is wrong because when something is based on something wrong then it is wrong. The orientalists have established and suspected that the word asbathan becomes the ma'dud for the 'adad ithnatay 'asyrata. However, that is the wrong determination.

In that verse, in fact, there is one word that was disposed of which is the word firqatan or qabilatan. And the disposed word is the ma'dud for the 'adad ithnatay 'asyrata. Thus, the word asbäthan according to Arabic syntax becomes badal of the ma'dud which is disposed of and the word umaman becomes badal after the badal. ${ }^{22}$ So, when we add the disposed word into the verse it becomes,

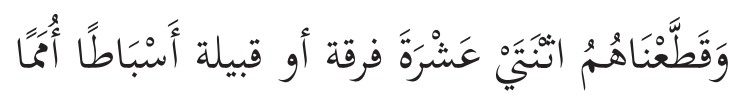

As it is known that disposing of the ma'dud in a sentence is constituted by the Arab syntactic theories. Among the examples of disposing of the ma'dud in a sentence are contained in the Qur'an Allah says, "And upon them, there are nineteen (guardian angels)."

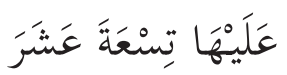

There is one word that is disposed from the verse which is the word malakan. And the disposed word is the ma'dud for 'adad tis'ata 'asyara. So when we add the disposed word into the verse it becomes,

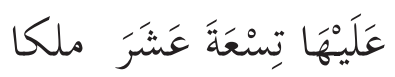

21 Al-Ghulayainiy, 175.

22 Abu Hayyan, Tafsir al-Babr al-Mubith (n.p.: Dar al-Fikr, 1983), 198. 
As for the fourth verse in Surah at-Tahrim Allah says, "If you both repent to Allah, then, in fact, your heart has been inclined (to receive kindness).”

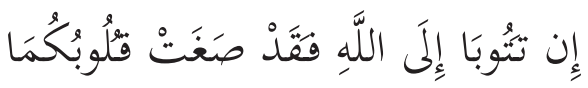

The Arabic rendering of this verse in tatuba ila Allah fa qad shaghat qulubukuma. Al-Baidawi says that Hafsha and 'Aisyah were being addressed with this verse. But despite of this, the Arabic word qulubukuma is in the plural form and it related to the pronoun kuma. There is an error in this verse because how can two people have more than two hearts. Therefore the Qur'an should have said qalbakuma. ${ }^{23}$

In fact, the arrangement of the word in the verse that has been used in the Qur'an is a well-known word order and it is the most widely used. Some verses have been found using such that kind of wording. One of it states in Q.S. al-Ma'idah [5]: 38 Allah says, "The man who stole and the woman who stole, cut their both hands."

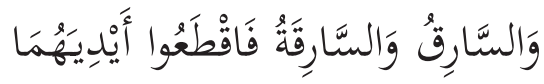

Need to know that actually, the order of words in these verses are all inseparable from the theories of Arabic syntax. The Arabic syntax experts have included and explained such wordings in their essays. Truly placing the plural form in the place of the double form or mutsanna is allowed in the theories of Arabic syntax. ${ }^{24}$

And the wording as in the verse-which mentions the plural form but the meaning of the word is a singular or double form-is a rule that the Arabs do in their language. ${ }^{25}$

From the theories that have been described above, it can be concluded that such wording is a common case among Arabs. Also

23 Hayyan, 185.

24 Hayyan, 222.

25 Jalal ad-Din as-Suyuthi, al-Mu§̧ir fi Ulum al-Lughah wa Anwa'uba (Beirut: Munshawarat al-Maktabah al-'Ashriyyah, 2014), 333. 
found in some syi ir written by the Arabs using the wording as in the Surah at-Tahrim. Among them are the syitir of Khitam al-Mujasyi'iy,

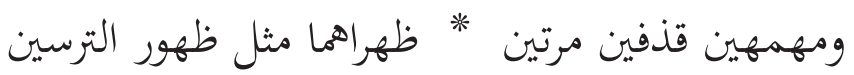

Indeed the poet Khitam al-Mujasyi'iy has combined two wordings of this case namely the first by matching to the word (ظهراهما) and it is the origin. And the second is by mentioning plural form as in word (ظهورالترسين).

The commentator explains that when the wording uses a double form, it will incriminate the Arabs in speaking. So when the sentence is safe from coercion, the phrase will change from the double form to the plural form. ${ }^{26}$

Therefore, there is no Arabic syntax error from the wording of the verse in Surah at-Tahrim. In fact, the verse is certainly based on the syntactic theories of Arabic and it based on the way of speaking Arabs as well. And that error is only from the people who do not understand how is the speaking of the Arabs and their ignorance of such forms and word orders.

Indeed, what is believed by 'Abdallah 'Abd al-Fadi is a defective belief because in fact when something is built upon the unlawful then it is wrong. And it would be ambiguous because of the flawed thing. And he also thought that the words in the Qur'an were wrong because he did not know the signs of rafa' except dlammah, signs of nashab except fathah, and the signs of jar except kasrah.

So if 'Abdallah 'Abd al-Fadi and the other orientalists refer to Arabic syntax books and commentaries, surely they will find and know in fact the words and verses in the Qur'an have absolutely no errors, moreover, Qur'an is based on the sciences of the Arabic and especially the sciences of Arabic syntax and tafsir. As it known that the tafsir is the main knowledge of the study of the Qur'an. ${ }^{27}$

26 Muhammad Thahir ibn 'Ashur, Tafsir at-Tahrir wa at-Tanwir (Libya: ad-Dar alJamahiriyyah, 2010), 356.

27 Ibn 'Ashur, 44. 


\section{Conclusion}

From the research described above, it can be concluded that 'Abdallah 'Abd al-Fadi is an orientalist who doubts the perfection and authenticity of Qur'an from all aspects. And one of the aspects is the language of Qur'an that related to the theory of the Arabic syntax which is the theory of 'adad and ma'dud. His thoughts are poured in a book entitled is the Qur'an infallible. His states that the Qur'an has two errors regarding the theory of 'adad and ma'dud which stated at Surah al-A'raf and Surah at-Tahrim. However the thoughts of 'Abdallah 'Abd al-Fadi against the two verses of the Qur'an are wrong and this is due to his lack of accuracy with Arabic theories, especially the theories of Arabic syntax. 


\section{REFERENCES}

Abbah, Muhammad al-Mukhtatar Walad. Tarikh an-Nabwiy al-'Arabiy. Libanon: Dar al-Kutub al-'Ilmiyyah, 2008.

Agustiar. "Orientalis dan Perannya dalam Mempelajari Bahasa Arab”, Jurnal Usbuluddin 17, no. 2 (2011).

Albab, Ulil. "Performansi dan Gramatika Bahasa Arab Sebagai Bahasa Kedua", Arabiyat: Jurnal Pendidikan Bahasa Arab dan Kebahasaaraban 2, no. 1 (2015).

Arif, Syamsuddin. "Al-Qur'an, Orientalisme, dan Luxenberg", Afkar: Jurnal Akidah dan Pemikiran Islam 6, no. 1 (2005).

Daud, Muhammad Muhammad. Kamal al-Lughah al-'Arabiyyah baina Haqa'iq al-I'jaz, wa Awham al-Khushum. Al-Qahirah: Maktabah al-Adab, 2007.

Daulay, Muhammad Roihan. "Studi Pendekatan Al-Qur'an”, Jurnal Thariqah Imiah 1, no. 1 (2014).

Fadal, Kurdi. "Pandangan Orientalis terhadap Al-Qur'an: “Teori Pengaruh" Al-Qur'an Theodor Nöldeke”, Jurnal Religia 14, no. 2 (2011).

al-Fadi, 'Abdallah 'Abd. Is the Qur'an Infallible? Austria: Light of Life, 2001.

al-Ghulayainiy, Muthafa. Jami' ad-Durus al-Arabiyyah. Al-Qahirah: Dar as-Salam, 2009.

Hayyan, Abu. Tafsir al-Babr al-Mubith. n.p.: Dar al-Fikr, 1983.

Ibn 'Ashur, Muhammad Thahir. Tafsir at-Tabrir wa at-Tanwir. Libya: ad-Dar al-Jamahiriyyah, 2010.

Jamil, Jamat. "Fi'il Mu'tal dalam Buku Akblak lil Banin Juz 1 Karya Umar bin Ahmad Baraja': Analisis Morfofonemis", Journal of Arabic Learning and Teaching 3, no. 3 (2014).

Kholik, Abdul. "Sunnah dalam Perspektif Orientalis", Jurnal ElIslam 2, no. 2 (2015). 
Luthfan, Muhammad Aqil. "Orientalisme: antara Lawan dan Kawan”, Jurnal Wahana Akademika 15, no. 1 (2013).

Pransiska, Toni. "Konsep I'rab dalam Ilmu Nahwu”, Jurnal al-Mahara 1, no. 1 (2015).

Qadli, Muhammad Mahmud. I'rab Al-Qur'an Al-Karim. Al-Qahirah: Dar ash-Shahwah, 2010.

Said, Edward Wadie. Orientalism. London: Penguin Books, 2003. as-Suyuthi, Jalal ad-Din. Al-Mu乏hir fi 'Ulum al-Lughah wa Anwa'uha. Beirut: Munshawarat al-Maktabah al-'Ashriyyah, 2014.

Tidjani, Amnah. "Klarifikasi al-Darwish atas Pandangan Orientalis Tentang Kontradiksi Ayat Al-Qur'an dengan Kaidah Nahw", Mutawatir:Jurnal Keilmuan Tafsir Hadits 4, no. 1 (2014).

Yusuf, Khaeruddin. “Orientalis dan Duplikasi Bahasa Al-Qur'an: Telaah dan Sanggahan atas Karya Christoph Luxenberg", Hunafa: Jurnal Studia Islamika 9, no. 1 (2012). 
Fakhrur Razi Mohd Rafi, Yayan Nurbayan and M. Zaka Al Farisi 